Note

\title{
A De Novo L330S Point Mutation in Thyroid Hormone Receptor Beta Gene in a Thai Female with Resistance to Thyroid Hormone
}

\author{
SASITORN DITUDOMPO, Boonsong ONGPHIPHADHANAKUL, SUWANNEE CHANPRASERTYOTIN \\ AND RAJATA RAJATANAVIN
}

Department of Medicine and Research Center, Ramathibodi Hospital, Mahidol University, Bangkok 10400, Thailand

\begin{abstract}
In the present study, we report a Thai female with a de novo mutation in thyroid hormone receptor- $\beta$ $(T R \beta)$ gene causing resistance to thyroid hormone $(\mathrm{RTH})$. The patient was a 19 year-old woman who presented with goiter for 1 year. Except for tachycardia she had no signs of thyrotoxicosis. Previously she was treated with propylthiouracil based on the diagnosis of thyrotoxicosis for 9 months and her goiter became more enlarged. The patient was the only child of the family. Her parents were alive and healthy, and did not have goiter or any other thyroid diseases. Physical examination revealed no sign of thyrotoxicosis. Her thyroid gland was diffusely enlarged with an estimated weight of $100 \mathrm{gm}$. Laboratory determinations revealed elevated free $\mathrm{T} 4, \mathrm{~T} 3$ and nonsuppressed TSH levels. Exon 9 of the TR $\beta$ gene was amplified by PCR and the DNA sequence was determined by dye terminator cycle sequencing. Heterozygous point mutation in which $\mathrm{T}$ was replaced by $\mathrm{C}$ was detected at position 1274 (TTG to TCG) corresponding to a leucine to serine substitution at codon 330 . No mutation was found in the parents indicating that the mutation was de novo. The nucleotide change created a restriction site for Taq 1 restriction endonuclease and the mutation was confirmed by restriction fragments length polymorphism. The same nucleotide change has been reported in a family with RTH.
\end{abstract}

Key words: Resistance to thyroid hormone, Mutation, Genetics

(Endocrine Journal 46: 825-829, 1999)

RESISTANCE to thyroid hormone (RTH) is a syndrome of reduced clinical manifestation of thyroid hormone action relative to the circulating thyroid hormone levels [1, 2]. Affected individuals often have goiter but are otherwise asymptomatic. Most cases of RTH are caused by mutations in exon 9 or 10 of thyroid nuclear receptor (TR) $\beta$ gene [3-5] and are mostly inherited as an autosomal dominant disorder [6-9]. A minority of cases appear to be sporadic [10, 11] or autosomal recessive in inheritance $[12,13]$. Point mutation L330S has been reported in familial

Received: January 25, 1999

Accepted: August 11, 1999

Correspondence to: Boonsong ONGPHIPHADHANAKUL, M.D., Division of Endocrinology and Metabolism, Department of Medicine, Ramathibodi Hospital, Rama 6 Rd., Rajthevi, Bangkok 10400, Thailand
RTH. In the present study, we report a case of RTH in Thais associated with de novo occurrence of this mutation.

\section{Materials and Methods}

\section{Patient}

The patient was a 19-year-old female at presentation with a chief complaint of goiter for 1 year. She also complained of palpitation but was otherwise asymptomatic. She was treated with propylthiouracil (PTU) after her thyroid function test was mistakenly interpreted as thyrotoxicosis. After treatment, the goiter became more enlarged, at which point she came to our hospital. She was healthy otherwise with regular menses which commenced 
when she was 13 years old. She was the only child of the family. Her parents were healthy and did not have any thyroid disorder.

Physical examination was normal except for a goiter which was $100 \mathrm{gm}$ in estimated weight. No hearing defect was detected on audiogram. Thyroid function tests, while she was on PTU, showed elevated free T4, T3 and nonsuppressed TSH (TSH, $11.7 \mu \mathrm{U} / \mathrm{ml}$; free $\mathrm{T} 4,4.8 \mathrm{ng} / \mathrm{dl} ; \mathrm{T} 3,285.0 \mathrm{ng} / \mathrm{dl}$ ). After PTU was stopped for 3 months, blood tests revealed elevated free T4 and T3. TSH was still nonsuppressed (TSH, $6.9 \mu \mathrm{U} / \mathrm{ml}$; free T4, $3.9 \mathrm{ng} / \mathrm{dl}$; $\mathrm{T} 3,281.0 \mathrm{ng} / \mathrm{dl}$ ). Both her father (TSH, $1.0 \mu \mathrm{U} / \mathrm{ml}$; free T4, $1.3 \mathrm{ng} / \mathrm{dl}$; T3, $96.1 \mathrm{ng} / \mathrm{dl}$ ) and mother (TSH, $1.4 \mu \mathrm{U} / \mathrm{ml}$; free T4, $1.4 \mathrm{ng} / \mathrm{dl} ; \mathrm{T} 3,80.0 \mathrm{ng} / \mathrm{dl}) \mathrm{had}$ normal thyroid function tests. Other routine biochemical tests while she was not taking PTU were normal except for mild elevation of ALT and cholesterol levels (Table 1). Her serum sex hormone binding globulin level was $45.5 \mathrm{mmol} / \mathrm{L}$ which was within normal range $(16-120 \mathrm{mmol} / \mathrm{L})$. To assess suppressibility of TSH after excess thyroid hormone, $\mathrm{L}-\mathrm{T}_{3} 40,80$ and $160 \mu \mathrm{g}$ was administered to the patient for 3 days at each dose and TSH was assessed after the completion of each dose. Increasing doses of L$\mathrm{T}_{3}$ resulted in progressive suppression of basal TSH levels as shown in Table 2. Likewise, increased suppression of TRH-stimulated TSH levels was also demonstrated with increasing doses of $\mathrm{L}^{-\mathrm{T}_{3}}$ (Fig. 1). The patient was clinically euthyroid except for diarrhea when she was taking $160 \mu \mathrm{g}$ of $\mathrm{L}_{-} \mathrm{T}_{3} \mathrm{MRI}$ of the pituitary revealed normal size of pituitary gland with convexity of superior surface and Ill-defined border of hyposignal intensity on $\mathrm{T} 1 \mathrm{~W}, \mathrm{~T} 2 \mathrm{~W}$ with in-

Table 1. Results of routine biochemical tests after PTU was stopped for 3 months.

\begin{tabular}{lcc}
\hline \multicolumn{1}{c}{ Chemistry } & Result & Normal Range \\
\hline Fasting plasma glucose (mg/dl) & 94 & $70-110$ \\
Creatinine (mg/dl) & 0.6 & $0.6-1.2$ \\
Uric acid (mg/dl) & 6.0 & $4.4-8.1$ \\
Sodium (mmol/L) & 139 & $135-145$ \\
Potassium (mmol/L) & 4.1 & $3.6-5.0$ \\
Chloride (mmol/L) & 106 & $101-111$ \\
Carbon dioxide (mmol/L) & 23.7 & $21-31$ \\
Calcium (mg/dl) & 9.6 & $8.8-10.0$ \\
Inorganic phosphorus (mg/dl) & 4.1 & $2.8-4.7$ \\
Total bilirubin (mg/dl) & 1.6 & $0.2-1.0$ \\
Direct bilirubin (mg/dl) & 0.5 & $0.1-0.5$ \\
Alkaline phosphatase (U/L) & 56 & $20-90$ \\
Cholesterol (mg/dl) & 247 & $140-240$ \\
AST (U/L) & 39 & $14-33$ \\
ALT (U/L) & 73 & $6-36$ \\
Total protein (g/L) & 88 & $66-84$ \\
Albumin (g/L) & 48.2 & $42-52$ \\
\hline
\end{tabular}

Table 2. Basal serum thyroid hormones and TSH concentrations after increasing ${\mathrm{L}-\mathrm{T}_{3}}_{3}$

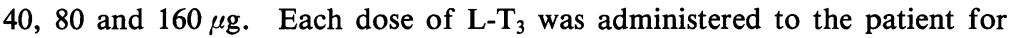
3 days.

\begin{tabular}{lcccc}
\hline & Basal & $\begin{array}{c}\mathrm{L}-\mathrm{T}_{3} \\
40 \mu \mathrm{g} / \mathrm{day}\end{array}$ & $\begin{array}{c}\mathrm{L}-\mathrm{T}_{3} \\
80 \mu \mathrm{g} / \mathrm{day}\end{array}$ & $\begin{array}{c}\mathrm{L}-\mathrm{T}_{3} \\
160 \mu \mathrm{g} / \text { day }\end{array}$ \\
\hline TSH $(\mu \mathrm{U} / \mathrm{ml})$ & 2.2 & 1.2 & 0.6 & 0.4 \\
Free T4 $(\mathrm{ng} / \mathrm{dl})$ & $>6$ & $>6$ & 4.6 & 3.3 \\
T3 $(\mathrm{ng} / \mathrm{dl})$ & 212 & 210 & 329 & $>600$ \\
\hline
\end{tabular}




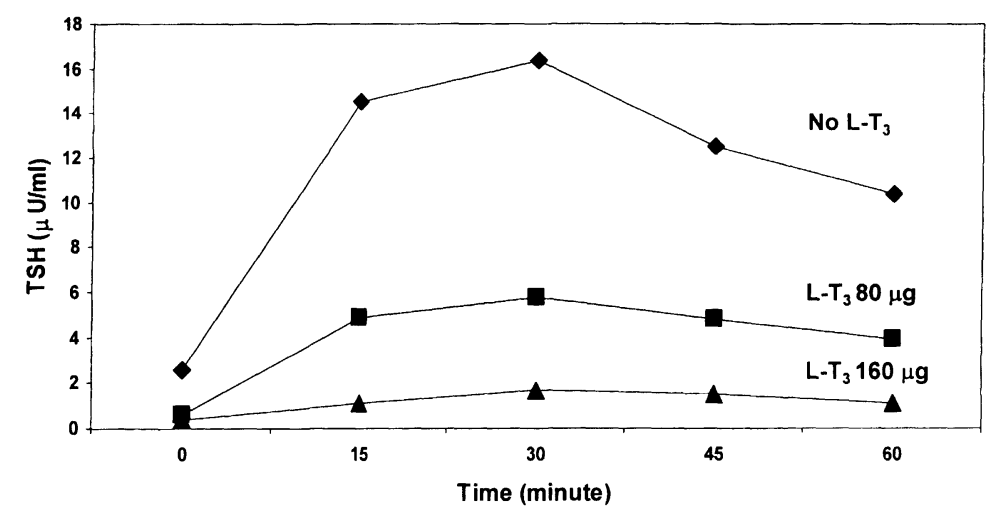

Fig. 1. TSH concentrations $(\mu \mathrm{U} / \mathrm{ml})$ after increasing doses of $\mathrm{L}-\mathrm{T}_{3}(\mu \mathrm{g} / \mathrm{day})$.

homogeneous enhancement lesion at the anterior lobe of pituitary gland compatible with microadenoma was noted.

\section{Mutational analysis of exon 9 of TR $\beta$}

\section{Direct sequencing of exon 9 of $T R \beta$}

The genomic DNA of the patient and her parents was extracted from peripheral leukocytes. Exon 9 of TR $\beta$ gene was amplified by PCR with the primers: forward, 5'-GATCTGCAGGCTCTTTGGATGCCCACTAAC and reverse, 5'-AGTGAATCACAGAAGGTTATTCCTATTGC. The DNA fragments were then subjected to direct dye cycle sequencing (ABI Prism 310).

\section{Confirmation of the mutation}

The nucleotide change also created a restriction site for Taq 1 restriction endonuclease. PCR product of exon 9 was digested with Taq 1 restriction endonuclease and the product was then resolved on $1.4 \%$ agarose gel with ethidium bromide staining.

\section{Results}

Nucleotide sequencing revealed a novel heterozygous thymidine to cytosine substitution at codon 330 in the patient. No nucleotide change was detected in her parents (Fig. 2). The mutation resulted in the amino acid replacement of leucine by serine. The nucleotide change also created a restriction site for Taq 1 restriction endonuclease. Digestion of the PCR product of exon 9 by Taq 1 restriction endonuclease resulted in a 430 and two approximately

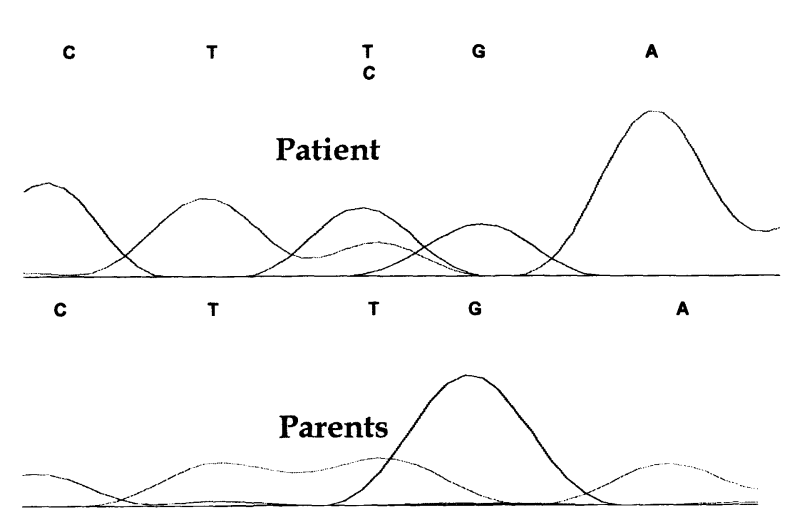

Fig. 2. Dye cycle sequencing of exon 9 to $\operatorname{TR} \beta$ gene revealed a heterozygous thymidine to cytosine substitution at codon 330 in the patient. No nucleotide change was detected in her parents.

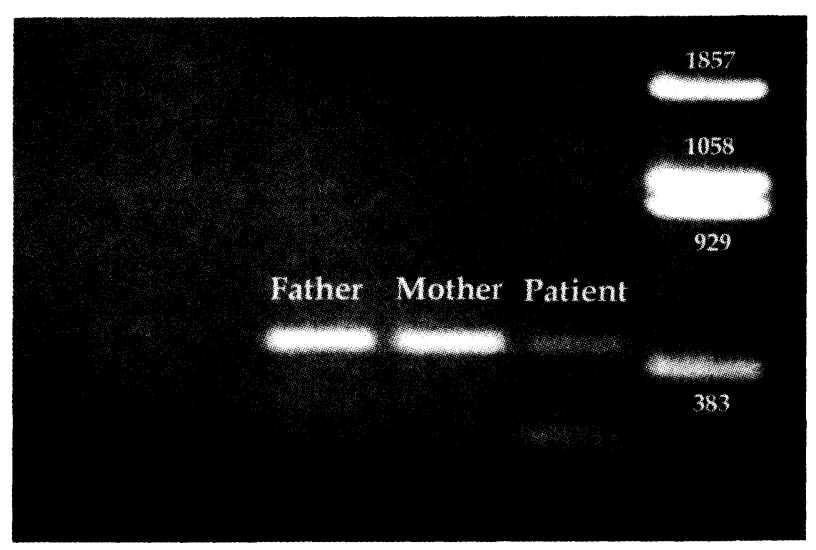

Fig. 3. PCR restriction fragments length polymorphism analysis of exon 9 of TR $\beta$ gene. Digestion of the PCR product of exon 9 by Taq 1 restriction endonuclease resulted in a 430 and two approximately 220 basepair fragments in the patient. No digestion was demonstrated in her parents. 
220 basepair fragments in the patient while only 430 basepair fragments were present in her parents (Fig. 3).

\section{Discussion}

Clinical presentations of RTH involve mutiple organ systems. Like the majority of reported cases [1], goiter was the major presenting feature in our patient. The goiter is likely to be related to thyroidal stimulation by the elevated TSH. However, a number of RTH subjects still have goiter despite TSH in the normal range $[1,15]$. This can be partly explained by the increased biological activity of TSH from subjects with RTH compared to controls [16]. Elevated thyroid hormones and goiter have been mistakenly interpreted as hyperthyroidism and treated as such with antithyroid drug which would not ameliorate the patient's problem but might induce enlargement of the goiter as demonstrated in our patient. This emphasizes the need for more awareness of the clinical features of RTH among practitioners. Our patient also compained of palpitation which mimics the symptoms of hyperthyroidism. Palpitation and tachycardia have been reported in RTH despite evidence of euthyroidism in other tissues. Tissue distribution of TR isoforms has been implicated in the difference in responsiveness among various organ systems $[17,18] . \operatorname{TR} \beta$ is involved in the development of the cochlea [19] and hearing defect has been reported in a minority of subjects [1]. No evidence of hearing disturbance was evident in our patients.

To date more tha 450 cases of RTH have been reported. RTH is almost exclusively caused by the mutation in T3-binding domain of TR $\beta$ gene corresponding to the region encompassing exons 9 and 10. More than 50 mutations in the $\operatorname{TR} \beta$ have been reported [20]. All mutations clustered around 2 areas, from codon 310-349 and codon 429-460. In terms of inheritance, RTH can be inherited in autosomal dominant, autosomal recessive or sporadic manner. However, almost all demonstrated an autosomal dominant inheritance with dominant negative feature [21, 22]. In Thais, the first case was reported in 1997 [14] and the subject possessed a known mutation in exon 9 (A317T). Similar to the first Thai patient, our patient developed the disorder de novo. No evidence of thyroid dysfunction or mutation of TR $\beta$ gene was detected in her parents. The L330S mutation in our patient has been previously reported in familial RTH [23]. Unlike the patients in that report, the nucleotide change in our patient represents a de novo mutation since no such mutation was found in her parents. In terms of clinical features, our patient has no thyroid dysfunction except tachycardia whereas the proband in the previous study showed features of both hyper- and hypothyroidism. This demonstrates the clinical variability of RTH even in subjects with identical mutation.

\section{References}

1. Refetoff S, Weiss RE, Usala SJ (1993) The syndrome of resistance to thyroid hormone. Endocr Rev 14: 348-399.

2. Refetoff S (1990) Resistant to thyroid hormone revisited. Thyroid Today 13: 1-11.

3. Usala SJ, Tennyson GE, Bale AE, Lash RW, Gesundheit N, Wondisford FE, Accili D, Hauser P, Weintraub BD (1990) A base mutation of c-erbA $\beta$ thyroid hormone receptor in a kindred with generalized thyroid hormone resistance. J Clin Invest 85: 93100.

4. Usala SJ, Menke JB, Watson TL, Berard WE, Bradley C, Bale AE, Lash RW, Weintraub BD (1991) A new point mutation in the 3,5,3'-triiodothyroninebinding domain of c-erbA $\beta$ thyroid hormone receptor is tightly linked to generalized thyroid hormone resistance. J Clin Endocrinol Metab 72: 32-38.

5. Sakurai A, Takeda K, Ain K, Ceccarelli P, Nakai A, Seino S, Bell GI, Refetoff S, DeGroot LJ (1989) Generalized resistance to thyroid hormone associated with mutation in ligand-binding domain of the human thyroid hormone receptor $\beta$. Proc Natl Acad Sci USA 86: 8977-8981.

6. Brooks $\mathrm{MH}$, Barbato $\mathrm{AL}$, Collin S, Garbincius J, Neidballa RG, Hoffman D (1981) Familial thyroid hormone resistance. AM J Med 71: 414-421.

7. Smallridge RC, Parker RA, Wiggs EA, Rajagopal KR, Fein HG (1989) Thyroid hormone resistance in a large kindred: physiologic, biochemical, pharmacologic, and neuropsychologic studies. Am J Med 86: 289-296.

8. Magner JA, Patric P, Manezes-Ferreira MM, Stelling 
M, Weintraub BD (1986) Familial generalized resistant to thyroid hormone: report of three kindreds and correlation of patterns of affected tissues with binding of [ $\left.{ }^{125} \mathrm{I}\right]$ triiodothyronine to fibroblast nuclei. $J$ Endocrinol Invest 9: 459-470.

9. Gharib H, Klee GG (1985) Familial euthyroid hyperthyroxinemia secondary to pituitary and peripheral resistance to thyroid hormones. Mayo Clin Proc 60: 9-15.

10. Brucker-Davis F, Skarulis MC, Grace MB, Benichou J, Hauser P, Wiggs E, Weintraub BD (1995) Genetic and clinical features of 42 kindreds with resistance to thyroid hormone. The National Institutes of Health prospective study. Ann Intern Med 123: 572-583.

11. Adam M, Matthews C, Colligwood TN, Tone Y, Beck-Peccoz, Chatterjee KK (1994) Genetic analysis of 29 kindreds with generalized and pituitary resistance to thyroid hormone. Identification of thirteen novel mutations in the thyroid hormone receptor beta gene. J Clin Invest 94: 506-515.

12. Takeda K, Balzano S, Sakurai A, DeGroot LJ, Refetoff S (1991) Screening of nineteen unrelated families with generalized resistance to thyroid hormone for known point mutations in the thyroid hormone receptor $\beta$ gene and the detection of a new mutation. $J$ Clin Invest 87: 496-502.

13. Takeda K, Sakurai A, Degroot LJ, Refetoff S (1992) Recessive inheritance of thyroid hormone resistance caused by complete deletion of the protein-coding region of thyroid hormone receptor-beta gene. J Clin Endocrinol Metab 74: 49-55.

14. Sunthornthepvarakul T, Angsusingha K, Likitmaskul $S$, Ngowngaramratana S, Refetoff S (1997) Mutation in the thyroid hormone receptor $\beta$ gene (A317T) in a Thai subject with resistance to thyroid hormone. Thyroid 7: 905-907.

15. Beck-Peccoz P, Chatterjee VKK (1994) The variable clinical phenotype in thyroid hormone resistance syn- drome. Thyroid 4: 225-232.

16. Persani L, Asteria C, Tonacchera M, Vitti P, Chatterjee VKK, Beck-Peccoz P (1994) Evidence for secretion of thyrotropin with enhance bioactivity in syndrome of thyroid hormone resistance. J Clin Endocrinol Metab 78: 712-719.

17. Meier CA, Dickstein BM, Ashizawa K, McClaskey JH, Muchmore P, Ransom SC, Menke JB, Hao EH, Usala SJ, Bercu BB (1992) Variable transcriptional activity and ligand binding of mutant $\beta 13,5,3^{\prime}$-triiodothyronine receptors from four family with generalized resistance to thyroid hormone. Mol Endocrinol 6: 248-258.

18. Usala SJ (1991) Molecular diagnosis and characterization of thyroid hormone resistance syndromes. Thyroid 1: 361-367.

19. Bardley DJ, Towle HC, Young III WS (1994) $\alpha$ and $\beta$ thyroid hormone receptor (TR) gene expression during auditory neurogenesis: evidence for TR isoformspecific transcriptional regulation in vivo. Proc Natl Acad Sci USA 91: 439-443.

20. Refetoff S, Weiss RE, Usala SJ, Hayashi Y (1994) The syndrome of resistance to thyroid hormone: update 1994. Endocr Rev 3: 336-343.

21. Chatterjee VKK, Nagaya T, Medison LD, Datta Srentoumis A, Jameson JL (1991) Thyroid hormone resistance syndrome: inhibition of normal receptor function by mutant thyroid hormone receptors. $J$ Clin Invest 87: 1977-1984.

22. Sakurai A, Miyamoto T, Refetoff S, DeGroot LJ (1991) Dominant negative transcriptional regulation by a mutant thyroid hormone receptor $\beta$ in a family with generalized resistance to thyroid hormone. $\mathrm{Mol}$ Endocrinol 5: 988-994.

23. Pohlenz J, Wildhardt G, Zabel B, Willgerodt $\mathrm{H}$. Resistance to thyroid hormone in a family caused by a new point mutation L330S in the thyroid receptor (TR) beta gene. Thyroid 1997; 7: 39-41. 